San Antonio Review • San Antonio Review (Issue 2 | Winter 2019)

\title{
Sister Cities
}

\author{
Abby Mangel
}

Published on: Jun 09, 2018

Updated on: Aug 03, 2020

DOI: $10.21428 / 9 b 43 c d 98.9413 a b 1 b$

License: Creative Commons Attribution 4.0 International License (CC-BY 4.0). 
I love you, Kumamoto. But my missions are in a state of decay. The limestone aqueducts, once traversing proudly alongside the Piedras Creek, the ones that pumped crystalline liquid into the mouths of my native born children, are dried. They too have crumbled under the heat of June air raids; they are mercury to the touch. A foolish child even took a knife and scrawled into my mossy contoured places, 'Great Tit!' Yes, I have since relinquished my walls to such awful graffiti, so crass, so thoughtless - But I know that you would cackle at the irony, Kumamoto, like a perching songbird with a green breast. Your laughter was always an alarm call, but your hilltop castles from the sixteenth century tower above this smut and gunfire, impregnable. I see the bombs descending upon my palm-lined streets, but I know they first touched down upon your distant pavements; Our mutual calamity became the center that holds us together, our scarred and sunken ground zero. Dirty needles and cigarette butts people my gutters, but blackened children line yours under cherry blossoms. The same coordinates where a silver plane dropped an inferno onto your hot pink camellia flowers also was where a calico cat named Rita lighted its bushy tail on a burning candlewick, dissolving into the fierce southwestern sunshine, All while its careless owner took a siesta and dreamt of deer leaping over a wire fence. Now, that's what I call some hot pussy, Kumamoto! The earthquakes rage, but I love you still. - San Antone

Abby Mangel is a graduate of the English Language and Literature Master's Program at St. Mary's University. She earned a Bachelor of Arts with a double major in English and philosophy from Trinity University. She is a rock n' roll journalist, and she completed her Master's Thesis on Bob Dylan. 